\title{
Pengaruh Permainan Tradisional Dalam Meningkatkan Keterampilan Sosial Siswa SMP
}

\author{
Purwaka Hadi \\ Bimbingan dan Konseling, Universitas Negeri Negeri Makassar \\ Email: purwakahadi@gmail.com \\ Abdullah Sinring \\ Bimbingan dan Konseling, Universitas Negeri Negeri Makassar \\ Email: abdullah.fipunm@gmail.com \\ Farida Aryani \\ Bimbingan dan Konseling, Universitas Negeri Negeri Makassar \\ Email: Farayani77@yahoo.com
}

(Diterima: 14-November-2017; direvisi: 10-Maret-2018; dipublikasikan: 24-Juni-2018)

\begin{abstract}
This study aims to determine the description of traditional games as a medium of counseling in improving the social skills of students and know the influence of traditional games as a medium of counseling in improving students' social skills. The research used quasi experiment with Pretest-Posttest Control Group Design design research. The samples used purposive sampling with 12 experimental group and 12 control group. Instrument using social skill scale. The findings of this study reveal that 1) the level of social skills of students in SMP Negeri 18 Makassar before being treated in the form of traditional games are in the "low" category and after being given a traditional game increases or is in the 'high' category. 2) there is a significant positive effect of traditional games in improving students' social skills. That is, the students' social skills can be improved by the provision of traditional games.
\end{abstract}

Keyword: traditional games, social skill

\begin{abstract}
Abstrak: Penelitian ini bertujuan untuk mengetahui gambaran permainan tradisional sebagai media bimbingan konseling dalam meningkatkan keterampilan sosial siswa dan mengetahui pengaruh permainan tradisional sebagai media bimbingan konseling dalam meningkatkan keterampilan sosial siswa. Penelitian menggunakan quasi eksperimen dengan desain penelitian Pretest-Posttest Control Group Design. Pengambil sampel menggunakan purposive sampling dengan jumlah 12 orang kelompok eksperimen dan 12 orang kelompok kontrol.Instrumen menggunakan skala keterampilan sosial. Temuan penelitian ini mengungkapkan bahwa 1) tingkat keterampilan sosial siswa di SMP Negeri 18 Makassar sebelum diberi perlakuan berupa permainan tradisional berada dalam kategori "rendah" dan setelah diberi permainan tradisional meningkat atau berada dalam kategori "tinggi". 2) terdapat pengaruh positif yang signifikan permainan tradisional dalam meningkatkan keterampilan social siswa. Artinya, keterampilan sosial siswa dapat ditingkatkan dengan pemberian permainan tradisional.
\end{abstract}

Kata kunci: Permainan Tradisional, Keterampilan Sosial

Copyright (C) 2018 Universitas Negeri Makassar.. This is an open access article under the CC BY-NC-ND license (http://creativecommons.org/licenses/by-nc-nd/4.0/). 


\section{PENDAHULUAN}

Peserta didik sebagai individu merupakan makhluk sosial yang saling berhubungan dan membutuhkan orang lain dalam kehidupannya, sebagai manusia dalam bertingkah laku selalu berhubungan dengan lingkungan sosial dimana ia tinggal. Menjalin hubungan dengan individu lain merupakan bagian yang tidak pernah lepas dari kehidupannya, individu selalu berinteraksi dengan lingkungannya, baik itu dalam keluarga maupun di masyarakat luas.

Sebagai makhluk sosial, individu dituntut untuk mampu mengatasi segala permasalahan yang timbul sebagai hasil dari interaksi dengan lingkungan sosial dan mampu menampilkan diri sesuai dengan aturan atau norma yang berlaku. Oleh karena itu setiap individu dituntut untuk menguasai keterampilanketerampilan sosial dan kemampuan penyesuaian diri terhadap lingkungan sekitarnya. Siswa sebagai individu tersebut jika memiliki keterampilan sosial akan mampu menyesuaikan diri dengan lingkungan dimana dia berada khususnya dalam lingkungan kelas atau sekolah, sehingga tidak terjadi individu yang terisolir, tidak memiliki kepekaan terhadap orang lain atau susah bergaul di dalam sekolah. Individu yang memiliki keterampilan sosial yang tinggi cenderung mendapatkan penerimaan sosial yang baik dan menujukkan ciri-ciri yang menyenangkan, bahagia dan memiliki rasa aman (Hurlock, 1995).

Siswa adalah individu yang memiliki potensi baik yang harus dikembangkan. Salah satu tugas perkembangan yang harus dikuasai oleh siswa yang berada dalam fase perkembangan masa remaja adalah memiliki keterampilan sosial (sosial skill) untuk dapat menyesuaiakan diri dengan kehidupannya seharihari. Lynch dan Simpson (2010: 3), mengemukakan pengertian keterampilan sosial adalah "social skills are behaviors that promote positive interaction with others and the environment. Some of these skills include showing empathy, participation in group activities, generosity, helpfulness, communicating wiyh others, negotiating, and problem solving".

Matson dan Ollendick (Silondae, 2013) juga mengungkapkan bahwa keterampilan sosial sebagai kemampuan seseorang dalam beradaptasi secara baik dengan lingkungannya dan menghindari konflik saat berkomunikasi baik secara fisik maupun verbal. Keterampilan sosial pada siswa dapat dilihat dalam cara siswa melakukan interaksi, baik dalam hal bertingkah laku maupun dalam hal berkomunikasi dengan orang lain, sehingga nantinya dapat bermanfaat bagi kehidupannya baik di lingkungan keluarga maupun lingkungan masyarakat.

Problem dalam keterampilan sosial siswa disebabkan karena faktor lingkungan, keluarga, persahabatan dan solidaritas kelompok, (Bakhtiar, 2015). Kemudian hasil penelitian terhadap siswa SLTA di padang ditemukan bahwa ketidakmampuan siswa berhubungan sosial di sekolah maupun luar sekolah menghambat kegiatan belajar dan mengganggu hubungan kegiatan belajar dan mengganggu hubungan interaksi dengan orang lain. Sehingga siswa yang termasuk kategori ini tidak disukai teman-temannya, sering diperolok-olok, dikucilkan, diremehkan, sombong, kurang peka terhadap orang lain, dan mudah tersinggung. Hal tersebut terjadi karena semakin menurunnya kesediaan menyapa, kecenderungan untuk mengungkapkan perasaan secara agresif, dan merasa was-was jika mengemukakan ide atau gagasan, (Prayitno, 1997).

Ciri-ciri yang dikemukakan Goleman (1995) tersebut terkait dengan kecerdasan mosional (emotional intelegence), yaitu kemampuan seseorang mengendalikan diri dan menampilkan emosi dalam berhubungan dengan orang lain. Ciri-ciri individu yang memiliki keterampilan sosial secara umum terkait dengan kemampuan verbal, non verbal, dan kemampuan mengendalikan diri dalam berinteraksi dengan orang lain. Kemampuan tersebut diharapkan diterapkan individu dalam berinteraksi dengan orang lain, mulai dari tingkat rendah (seperti kontak mata, melakukan pembicaraan sederhana, dan mengatur nada suara) sampai tingkat tinggi (seperti meminta atau memberi informasi, menyelesaikan konflik antar pribadi, memberi atau menerima pujian, berempati, dan menunjukkan respon bersahabat terhadap orang lain). Calderella dan Merrel (Gimpel \& Merrell, 1998) mengemukakan 5 (lima) dimensi paling umum yang terdapat dalam keterampilan sosial yaitu : (a) Hubungan dengan teman sebaya (peer relation), ditujukkan melalui prilaku yang positif terhadap teman sebaya seperti memuji atau menasehati orang lain, menawarkan bantuan kepada orang lain, dan bermain bersama orang lain. (b) Manajemen diri (self-management), merefleksikan remaja yang memiliki emosional yang baik, yang mampu untuk mengontrol 
emosinya, mengikuti peraturan dan batasanbatasan yang ada, dapat menerima kritikan dengan baik; (c) Kemampuan akademik (Akademic), ditunjukkan melalui pemenuhan tugas secara mandiri, menyelesaikan tugas individual, menjalankan arahan guru dengan baik; (d) Kepatuhan (Compliance), menunjukkan remaja yang dapat mengikuti pelajaran dan harapan, menggunakan waktu dengan baik, membagikan sesuatu; (e) Perilaku assertive (Assertion), didominasi oleh kemampuankemampuan yang membuat seorang remaja dapat menampilkan yang tepat dalam situasi yang diharapkan.

Terkait berkembangnya kecanggihan teknologi serta dinamika komunikasi yang semakin modern menjadi salah satu penyebab berbagai nilai sosial di suatu masyarakat menjadi terkikis. Seiring dengan perkembangan teknologi dan komunikasi yang canggih ini, individu secara tidak langsung dibuat menjadi lebih individualistik. Kemajuan jaman memang bukan untuk dihindari, namun setidaknya bisa disaring untuk dijadikan hal yang positif dan berguna bagi kehidupan, bukan malah menjauhkan kita dari kehidupan sosial kita. Kecanggihan teknologi sebaiknya digunakan sebijak mungkin. Memanfaatkan teknologi bukan berarti kita melupakan budaya lokal. Menerapkan budaya lokal dalam keseharian terkadang dianggap kuno atau ketinggalan jaman, tanpa kita sadari sebenarnya banyak budaya lokal yang dapat diterapkan dalam keseharian kita yang dapat memberikan dampak positif salah satunya adalah permainan tradisional.

Permainan tradisional adalah permainan yang lebih mudah untuk didapatkan, tanpa biaya mahal, tanpa melupakan lingkungan sekitar, membuat kita lebih terlibat interaksi dengan teman sebaya, serta membuat anak-anak atau remaja sekarang tidak melupakan nilai-nilai budaya lokalnya yang lazimnya dilakukan oleh lebih dari satu orang, sehingga didalam proses bermain, anak dituntut untuk melakukan interaksi dengan lawan mainnya, selain itu didalam permainan tradisional juga terdapat aturan-aturan yang harus ditaati oleh setiap anak sehingga masing-masing anak bertanggung jawab terhadap aturan permainan. Harun (2014) menjelaskan bahwa permainan tradisional dikategorikan dalam tiga golongan yaitu untuk bermain (rekreatif), permainan untuk bertanding (kompetitif) dan permainan yang bersifat edukatif. Permainan tradisional yang bersifat rekreatif pada umumnya dilakukan untuk mengisi waktu senggang. Permainan tradisional yang bersifat kompetitif, memiliki ciri-ciri yang terorganisir, bersifat kompetitif, dimainkan paling sedikit 2 orang, mempunyai peraturan yang diterima bersama oleh pesertanya, sedangkan permainan tradisional yang bersifat edukatif, terdapat unsur-unsur pendidikan di dalamnya.

Melalui permainan seperti ini anak-anak diperkenalkan dengan berbagai macam keterampilan dan kecakapan yang nantinya akan mereka perlukan dalam menghadapi kehidupan sebagai anggota masyarakat. Inilah salah satu bentuk pendidikan yang bersifat non-formal di dalam masyarakat. Permainan-permainan seperti ini menjadi alat sosialisasi untuk anak-anak agar mereka dapat menyesuaikan diri sebagai anggota kelompok sosialnya. Senada dengan yang diungkapkan oleh Kasim (2017) bahwa permainan tradisional adalah salah satu warisan budaya yang diwariskan secara turun temurun yang memiliki nilai-nilai positif dalam pembentukan karakter anak (siswa) seperti sportivitas, kedisiplinan, kreativitas serta kemampuan sosial dan menjalin kerja sama dengan orang lain.

Berkaitan dengan potensi siswa dibidang sosial, layanan bimbingan konseling merupakan upaya yang dapat ditempuh dalam mengembangkan sikap-sikap positif seperti empati, kerja sama, tanggung jawab, dan kedisiplinan. Dalam memberikan layanan bimbingan konseling, guru BK di Makassar masih kekurangan media, dibutuhkan media yang dapat memberikan suasana yang menyenangkan dan menarik bagi siswa. Permainan ini dipilih karena permainan tersebut dilakukan dalam bentuk kelompok sehingga dapat menekankan aspek kerja sama, kekompakan, saling menghargai, mengendalikan diri atau emosi saat bermain, berempati, serta belajar bertanggung jawab dan disiplin pada peraturan permainan sehingga diharapkan dapat meningkatkan keterampilan sosial siswa. Tilaar (Silondae, 2013) mengungkapkan bahwa dalam upaya memperkuat jati diri bangsa dapat dilakukan melalui internalisasi nilai-nilai budaya lokal penting dalam memberi peluang pada siswa untuk mengapresiasikan masalah-masalah dan kemungkinan-kemungkinan pemecahannya menurut landasan nilai-nilai yang dianutnya. 


\section{METODE}

Penelitian ini adalah penelitian quasi eksperimen dengan jenis desain Pretest-Posttest Control Group Design, dengan sampel 12 orang kelompok eksperimen dan 12 orang kelompok kontrol yang dipilih melalui teknik purposive sampling. Instrumen yang digunakan adalah skala keterampilan sosial. Analisis data menggunakan teknik analisis statistik deskriptif menggunakan SPSS 20 for windows.

\section{HASIL DAN PEMBAHASAN}

Berdasarkan hasil pengelolaan data, maka hasil penelitian ini dapat dijelaskan sebagai berikut:

Tabel 1. Data Tingkat Keterampilan Sosial Siswa sebelum (pretest) dan setelah (postest) diberi perlakuan berupa permainan tradisional.

\begin{tabular}{cccccc}
\hline \multirow{2}{*}{ Interval } & \multirow{2}{*}{ Kategori } & \multicolumn{2}{c}{ Pretest Eksperimen } & \multicolumn{2}{c}{ Posttest Eksperimen } \\
\cline { 3 - 6 } $108-132$ & Sangat Tinggi & 0 & 0 & 1 & 8,33 \\
$83-107$ & Tinggi & 0 & 0 & 11 & 91,67 \\
$58-82$ & Rendah & 9 & 75 & 0 & 0 \\
$33-57$ & Sangat Rendah & 3 & 25 & 0 & 0 \\
\hline & Jumlah & $\mathbf{1 2}$ & $\mathbf{1 0 0}$ & $\mathbf{1 2}$ & $\mathbf{1 0 0}$ \\
\hline
\end{tabular}

Sumber: Hasil Skala Penelitian Kelompok Eksperimen

Tabel diatas menunjukkan bahwa tingkat keterampilan sosial siswa di SMP Negeri 18 Makassar sebelum diberikan permainan tradisional berada pada kategori sangat tinggi dan tinggi sebanyak $0(0 \%)$ siswa, kemudian pada kategori rendah sebanyak $9(75 \%)$ siswa, dan pada kategori sangat rendah sebanyak $3(25 \%)$ siswa.
Setelah diberikan perlakuan berupa permainan tradisional tingkat keterampilan sosial siswa menunjukkan perubahan positif yaitu mengalami peningkatan. Hal ini dapat dilihat dari tingkat keterampilan sosial siswa berada dalam kategori sangat tinggi sebanyak $1(8,33 \%)$ siswa, $11(91,67 \%)$ siswa berada pada kategori tinggi, dan $0(0 \%)$ siswa yang berada pada ketegori rendah dan sangat rendah.

Tabel 2. Data Tingkat Keterampilan Sosial Siswa sebelum (pretest) dan setelah (postest) diberi perlakuan berupa permainan tradisional.

\begin{tabular}{cccccc}
\hline Interval & Kategori & \multicolumn{2}{c}{ Pretest Eksperimen } & \multicolumn{2}{c}{ Posttest Eksperimen } \\
\cline { 3 - 6 } & & $\mathbf{F}$ & $\mathbf{P}(\boldsymbol{\%})$ & $\mathbf{F}$ & $\mathbf{P}(\mathbf{\%})$ \\
$108-132$ & Sangat Tinggi & 0 & 0 & 0 & 0 \\
$83-107$ & Tinggi & 0 & 0 & 1 & 8,33 \\
$58-82$ & Rendah & 10 & 83,33 & 10 & 83,34 \\
$33-57$ & Sangat Rendah & 2 & 16,67 & 1 & 8,33 \\
& Jumlah & $\mathbf{1 2}$ & $\mathbf{1 0 0}$ & $\mathbf{1 2}$ & $\mathbf{1 0 0}$ \\
\hline
\end{tabular}

Sumber: Hasil Skala Penelitian Kelompok Kontrol

Tabel diatas menunjukkan bahwa tingkat keterampilan sosial siswa di SMP Negeri 18 Makassar sebelum diberikan permainan tradisional berada pada kategori sangat tinggi dan tinggi sebanyak $0(0 \%)$ siswa, kemudian pada kategori rendah sebanyak $10(83,33 \%)$ siswa, dan pada kategori sangat rendah sebanyak $2(16,67 \%)$ siswa.

Setelah diberikan perlakuan berupa permainan tradisional tingkat keterampilan sosial siswa menunjukkan perubahan positif yaitu mengalami peningkatan pada 1 siswa. Hal ini dapat dilihat dari tingkat keterampilan sosial siswa berada dalam kategori sangat tinggi tinggi sebanyak $0(0 \%)$ siswa, $1(8,33 \%)$ siswa berada pada kategori tinggi, $10(83,34 \%)$ siswa berada pada kategori rendah, dan $1(8,33 \%)$ siswa yang berada pada ketegori sangat rendah.

Signifikansi perbedaan tingkat keterampilan sosial siswa sebelum dan setelah diberikan perlakuan berupa permainan 
tradisional menggunakan hasil perhitungan berdasarkan SPSS 20 for windows melalui uji statistik non parametrik Wilcoxon match pair test. Uji Wilcoxon $(Z)$ ini merupakan uji beda parameter rata-rata untuk dua sampel berpasangan.

Hipotesis penelitian ini adalah ada pengaruh permainan tradisional terhadap keterampilan sosial siswa SMP di Kota Makassar. Berdasarkan perhitungan dengan menggunakan SPSS 20 for windows melalui two related samples test terdapat signifikansi ratarata setelah perlakuan yaitu lebih rendah dari sebelum diberikan perlakuan pada kelompok eksperimen, hal itu dipertegas dari nilai gain skor pada kelompok eksperimen yaitu 24,08, kemudian setelah itu data tersebut dianalisis maka diperoleh nilai $\mathrm{Z}$ yaitu 3.062 dengan nilai Asymp Sig $=0,02<0,05$. Hal ini berarti $\mathrm{H}_{0}$ dinyatakan ditolak. Sehingga $\mathrm{H}_{1}$ dinyatakan diterima.

Tabel 3. Hasil Pengujian Hipotesis

\begin{tabular}{ccccc}
\hline Jenis Data & Mean Gain & $\mathbf{Z}$ & Asymp Sig & $\mathbf{H}_{\mathbf{0}}$ \\
\hline Eksperimen & 24,08 & $-3,032$ & 0,02 & Ditolak
\end{tabular}

\section{Sumber: Hasil pretest dan posttest}

Permainan tradisional yang lazimnya dimainkan oleh lebih dari satu orang anak sehingga didalam proses bermainnya anak dituntut untuk melakukan interaksi dengan lawan mainnya, selain itu didalam permainan tradisional juga terdapat aturan-aturan main yang harus ditaati oleh setiap pemain, sehingga mereka terlatih untuk disiplin. Apabila ada pemain yang tidak mematuhi aturan main, dia akan mendapatkan sanksi sosial dari temannya. Selain itu, menurut hasil penelitian yang dilakukan oleh Kurniati (2006) menunjukkan bahwa permainan tradisional dapat menstimulasi anak dalam mengembangkan kemampuan kerja sama, membantu anak dalam menyesuaikan diri, saling berinteraksi secara positif, dapat mengontrol dirinya, mengembangkan sikap empati terhadap teman, menaati aturan, serta menghargai orang lain.

Permainan tradisional merupakan salah satu cara yang dapat dilakukan untuk meningkatkan keterampilan sosial siswa, hal tersebut sesuai dengan keadaan siswa saat sebelum diberikan perlakuan permainan tradisional atau pretest. Hasil penelitian terhadap 12 siswa pada kelompok eksperimen menunjukkan bahwa tingkat keterampilan sosial yang rendah. Adapun ciri-ciri keterampilan sosial rendah yang ditunjukkan oleh siswa antara lain kurang mampu berinteraksi dengan baik dengan siswa yang lainnya, kurang mampu menyelesaikan konflik, dan memiliki empati yang rendah. Namun setelah diberikan perlakuan berupa permainan tradisional selama 7 kali pertemuan dan disetiap akhir pertemuan peneliti melakukan kegiatan refleksi, keterampilan sosial siswa mengalami perubahan yang positif atau mengalami peningkatan, dengan demikian dapat dikatakan bahwa permainan tradisional dapat mempengaruhi keterampilan sosial siswa.

\section{SIMPULAN DAN SARAN}

Berdasarkan hasil penelitian yang diperoleh dapat disimpulkan bahwa (1) tingkat keterampilan sosial siswa di SMP Negeri 18 Makassar sebelum diberi perlakuan berupa permainan tradisional berada dalam kategori "rendah" dan setelah diberi permainan tradisional meningkat atau berada dalam kategori 'tinggi". Dan (2) terdapat pengaruh positif yang signifikan permainan tradisional dalam meningkatkan keterampilan sosial siswa. Artinya, keterampilan sosial siswa dapat ditingkatkan dengan pemberian permainan tradisional.

Berdasarkan kesimpulan diatas maka disarankan untuk (1) perlu adanya guru BK membuat media yang menarik dan lebih banyak melibatkan interaksi antar siswa, sehingga siswa lebih terbiasa untuk berinteraksi dan bekerjasama dengan teman sebayannya. Dan (2) perlu adanya alokasi waktu bagi pelaksanaan layanan bimbingan dan konseling di sekolah, sehingga ada waktu yang efektif bagi guru BK untuk memberikan layanan bimbingan dan konseling.

\section{DAFTAR RUJUKAN}

Bakhtiar, M. I. (2015). Pengembangan Video Ice Breaking Sebagai Media Bimbingan 
Konseling. Jurnal Psikologi Pendidikan Dan Konseling, 1(2), 150-163. Retrieved from http://ojs.unm.ac.id/index.php/JPPK/arti cle/view/1816

Gimpel, G.A. \& Merrell, K.W.(1998). Social Skill of Children and Adolescents: Conceptualization, Assessment, Treatment. New Jersey: Lawrence Erlbaum Associates Publisher. http://www.questia.com/PM.qst?a=o\&d $=27773641$. Tanggal akses 14 September 2012 .

Harun. 2014. Pelaksanaan Permainan Tradisional "Massalo" dalam Bimbingan Kelompok untuk Meningkatkan Penyesuaian Sosial Siswa di SMA Negeri 1 Palopo. Tesis. Tidak diterbitkan. Makassar: Program Pascasarjana UNM

Hurlock, Elizabet. B (1995). Perkembangan Anak. Edisi Keenam. Jakarta.

Kasim, S. N. O. (2017). Pengembangan Permainan Tradisional Bugis Makassar sebagai Media Bimbingan Konseling dalam Meningkatkan Keterampilan Sosial Siswa. Jurnal Psikologi, Pendidikan, dan Konseling. 3(1), 45-52. Retrieved

from http://ojs.unm.ac.id/index.php/JPPK/arti cle/view/3016.
Kurniati, S. 2006. Program Bimbingan untuk Mengembangkan Keterampilan Sosial Anak Melalui Permainan Tradisional. Jurnal, (Online), (http://file.upi.edu/direktori/FIP/JUR_P GTK/197706112001122-

Euis_Kurniati/pedagogia.pdf

Lynch, S dan Simpson, C. 2010. Social Skills: Laying the Foundation for Success. Dimensions of Early Childhood, 38 (2), 3-12. Jurnal, (Online), (http://southernearlychildhood.org/uploa d/pdf/Volume_38_Issue_2_Full_Issue.p $\underline{\text { df) }}$

Prayitno. (1997). Pelayanan Bimbingan dan Konseling (SLTP). Jakarta: PT. Bina Sumber Daya MIPA

Silondae, P. D. (2013). Model Bimbingan Kelompok Berbasis Nilai Budaya Suku Tolaki untuk Meningkatkan Keterampilan Sosial Siswa. Jurnal, (Online),

(http://journal.unnes.ac.id/sju/index.ph p/jubk) 